TTR

Traduction, terminologie, rédaction

\title{
When Body, Emotion, and Translation Meet: A Proposal for a Reader- and Translator-Oriented Approach to Translation
}

\author{
Julia Constantino Reyes
}

Volume 32, numéro 2, 2e semestre 2019

La politique des microcentres : la traduction dans des contextes " mineurs " comme transfert culturel complexe

The Politics of Micro-Centers: Translation in "Minor" Contexts as Complex Cultural Transfer

URI : https://id.erudit.org/iderudit/1068908ar

DOI : https://doi.org/10.7202/1068908ar

Aller au sommaire du numéro

\section{Éditeur(s)}

Association canadienne de traductologie

ISSN

0835-8443 (imprimé)

1708-2188 (numérique)

Découvrir la revue

Citer cet article

Constantino Reyes, J. (2019). When Body, Emotion, and Translation Meet: A Proposal for a Reader- and Translator-Oriented Approach to Translation. TTR, 32(2), 185-215. https://doi.org/10.7202/1068908ar

\section{Résumé de l'article}

Cet article tente d'explorer de façon théorique certaines manières possibles par lesquelles la traduction peut remettre en question le binarisme et l'autorité en créant des liens entre les expériences de genre non-conforme et la traduction. Je propose une approche de la traduction plus flexible, orientée vers le lecteur et vers le traducteur, sur la base de la performativité, la narrativité, la théorie des émotions et de l'affect, la théorie féministe et la théorie queer, qui peuvent éventuellement contribuer à la transformation de certaines attentes encore rigides concernant la traduction comme un processus, un produit et un phénomène. L'article analyse comment les émotions et les éléments de performativité utilisés par la traduction féministe et queer peuvent contribuer à une reconceptualisation de la traduction basée sur un questionnement et saper la pensée binaire - et des concepts connexes tels que l'équivalence, la fidélité, l'unité, la cohérence et l'homogénéité - par la répétition, la différence et la provisionnalité. Un aspect central est que l’ambiguïté qui peut résulter de la rupture du binarisme dans la traduction et dans les corps et expériences de genre non conforme par le biais de mécanismes de performativité et d'émotions comme pratiques culturelles peut devenir un espace éthique de résistance et d'activisme. Cet espace peut dénoncer l'arbitraire des pratiques productrices de sens, proposer d'autres sites de sens et de savoir, et construire des récits plus souples. Cela peut se réaliser au moyen de la construction d'une honte et d'un inconfort productifs, émotions qui sont imprimées sur le corps. Ces émotions peuvent devenir un lien entre le lecteur et le traducteur, contribuant ainsi à la transformation de la traduction et des attentes de la lecture des traductions, paradigmes et pratiques.
Ce document est protégé par la loi sur le droit d'auteur. L'utilisation des services d'Érudit (y compris la reproduction) est assujettie à sa politique d'utilisation que vous pouvez consulter en ligne.

https://apropos.erudit.org/fr/usagers/politique-dutilisation/ 


\title{
When Body, Emotion, and Translation Meet: A Proposal for a Reader- and Translator-Oriented Approach to Translation
}

\author{
Julia Constantino Reyes \\ Universidad Nacional Autónoma de México
}

\begin{abstract}
This article attempts to explore, in a theoretical manner, some possible ways in which translation may question binaries and authority by creating links between sex-gender non-conforming experiences, and translation. I suggest a flexible, reader-oriented and translator-oriented approach to translation based on performativity, narrativity, theory of emotions and affect theory, feminist theory, and queer theory that can possibly contribute to the transformation of some still rigid expectations about translation as a process, a product, and a phenomenon. The article discusses how emotions and performativity elements used by feminist and queer translation may contribute to a reconceptualization of translation based on a questioning and undermining of binary thinkingand of related concepts such as equivalence, fidelity, unity, coherence, and homogeneity - through repetition, difference, and provisionality. A central point is that the ambiguity that can arise from breaking away from binary thinking in translation and in sex-gender non-conforming bodies and experiences through mechanisms of performativity and of emotions as cultural practices can become an ethical space of resistance and activism. Such a space may denounce the arbitrariness of meaning-producing practices, propose other sites of meaning and knowledge, and construct more flexible narratives. This may be accomplished through the construction of productive shame and discomfort, emotions which are impressed on the body. These emotions can become a link between reader and translator thereby contributing to the transformation of translation and of translation-reading expectations, paradigms, and practices.
\end{abstract}

Keywords: feminist translation, queer translation, emotion, body, performativity

\section{Résumé}

Cet article tente d'explorer de façon théorique certaines manières possibles par lesquelles la traduction peut remettre en question le binarisme et l'autorité en 
créant des liens entre les expériences de genre non-conforme et la traduction. Je propose une approche de la traduction plus flexible, orientée vers le lecteur et vers le traducteur, sur la base de la performativité, la narrativité, la théorie des émotions et de l'affect, la théorie féministe et la théorie queer, qui peuvent éventuellement contribuer à la transformation de certaines attentes encore rigides concernant la traduction comme un processus, un produit et un phénomène. L'article analyse comment les émotions et les éléments de performativité utilisés par la traduction féministe et queer peuvent contribuer à une reconceptualisation de la traduction basée sur un questionnement et saper la pensée binaire - et des concepts connexes tels que l'équivalence, la fidélité, l'unité, la cohérence et l'homogénéité - par la répétition, la différence et la provisionnalité. Un aspect central est que l'ambiguïté qui peut résulter de la rupture du binarisme dans la traduction et dans les corps et expériences de genre non conforme par le biais de mécanismes de performativité et d'émotions comme pratiques culturelles peut devenir un espace éthique de résistance et d'activisme. Cet espace peut dénoncer l'arbitraire des pratiques productrices de sens, proposer d'autres sites de sens et de savoir, et construire des récits plus souples. Cela peut se réaliser au moyen de la construction d'une honte et d'un inconfort productifs, émotions qui sont imprimées sur le corps. Ces émotions peuvent devenir un lien entre le lecteur et le traducteur, contribuant ainsi à la transformation de la traduction et des attentes de la lecture des traductions, paradigmes et pratiques.

Mots-clés: traduction féministe, traduction queer, émotion, corps, performativité

\section{Introduction}

An increase in the open demands for women's and sex-gender dissidents' rights has marked the second half of the 2010s. Voices have become much louder and more direct when acting against legal impunity and the state and social negligence that have characterized the official treatment of sexual and gender violence cases. This includes femicides and transfemicides, particularly in Latin America. The Latin American creation and endorsement of movements such as Marea Verde, \#elvioladorerestú, and \#MeToo are especially relevant given the high rates of gender violence in this part of the world. However, following these movements, there has been a backlash that has resulted in an alarming multiplication of cases of violence against women and sex-gender non-conforming people, as can be seen daily in the Mexican press (see Guerrero and Muñoz, 2016; Anon., 2019; Galván, 2019).

This situation is both a part and a result of global and local social, cultural, and legal narratives that, built on patriarchal and heteronormative gender and binary structures and norms, contribute to a 
narrow definition and recognition of "humanness" and "personhood." They construct and lead to the impression that some bodies and subject positions are more intelligible, and hence, more entitled to rights, and worthier than others, thereby excluding individuals that do not meet hegemonic definitions and expectations (see Butler, 2004). As part of their circular mechanism, such narratives ${ }^{1}$ create and reinforce contexts where cultural practices are originated and carried out, just as they provide the tools for an understanding and acceptance of those same practices. The effects of those narratives that have, through their repetition, created a strong naturalized social order that is still difficult to counterbalance, emphasize the need to insist on the social and political relevance of academic practices that may widen their scope and take an active part in questioning and transforming the social scene much in the sense announced by Judith Butler when she states:

Something besides theory must take place, such as interventions at social and political levels that involve actions, sustained labor, and institutionalized practice, which are not quite the same as the exercise of theory. [...] in all of these practices, theory is presupposed. We are all, in the very act of social transformation, lay philosophers, presupposing a vision of the world, of what is right, of what is just, of what is abhorrent, of what human action is and can be, of what constitutes the necessary and sufficient conditions of life. (2004, pp. 204-205)

Such may be the case of the reflection on translation. Needless to say, the practice of translation and translations as products have played a major role in the formation, reinforcement, and transformation of societies and cultures, since they are crucial in the construction, reproduction, and re-presentation of different configurations of narratives, images, and meanings (see Baker, 2010, p. 27). The practice of reflecting on the way translations have been and can be produced and what

1. I will be using the term "narratives" thinking of both the workings of time and syntagmatic relationality in the organization of actions and signs, as they appear as story and plot elements in narratology, and Mona Baker's use of the term, based on Walter Fisher's narrative paradigm, as "the everyday stories we live by" (2007, p. 3). Baker adds that "[o]ne of the effects of narrativity is that it normalizes the accounts it projects over a period of time so that they come to be perceived as self-evident, benign, uncontestable and non-controversial" (ibid., p. 11), very much following, as it will be seen, the model dynamics of performative utterances and illocutionary acts. The telling and re-telling of previous narratives can be a means of control that naturalizes order, roles, and interpretations, and reinforces authority (ibid., p. 21), as happens with mythical and foundational narratives on which "humanness" is constructed, which nevertheless can lead to the disassembling and reassembling of those narratives (see Butler, 2004, p. 13; Parrini and Brito, 2014, p. 8). 
this may imply, is another way of suggesting possible alternative ways of translating, but also possible ways of conceiving and discussing translation itself.

Translation and translators tend to be central actors in narrative processes since they contribute to the construction and reconstruction of textualities that are part of an overall cultural and social environment. Never neutral observers, they are potentially relevant agents since they play a role in processes of social transformation that are rooted in power dynamics, and are able to stand critically in the face of such dynamics (see Baldo, 2005, pp. 214-216; Wessegger, 2011, pp. 169-175). As seen polysystemically, translation/s can cause a new or different cultural and literary system to be affected and transformed at various levels - themes, repertoire, models, hierarchies, dynamics. This is also something that has to do with the political and social relevance of translation and translators in the way they take part in cultural and social transformations. ${ }^{2}$

Given this historical role of translation and translators in wider social and political narrative processes, I suggest a framework for a more flexible approach to translation-both its practice and the reflection on it - that is reader and translator oriented, and focuses on resignifying and undoing binaries and authority. This can affect normative expectations of translation that are currently based on the same binary narratives that seem to determine and justify the kind of gender discrimination and violence already mentioned. Moreover, it could lead to the gradual re-elaboration of narratives that structure social and cultural interactions if what nowadays is an academic exercise-commented translations as a graduating option in some Mexican universities, for example-could become a professional and publishing practice beyond academia. Such an approach could thus contribute to the creation of spaces for experimental translation and then to the gradual transformation of the Mexican literary polysystem from a feminist and LGBTIQ+ perspective.

2. This has been explored in many of the articles in Maria Tymoczko's Translation, Resistance, Activism (2010), in the texts in Nayelli Castro Ramírez' Traducción, identidad y nacionalismo en Latinoamérica (2013), and in Pilar Godayol's Tres escritoras censuradas: Simone de Beauvoir, Betty Friedan y Mary McCarthy (2017), where the role of specific translations as triggering or supporting social and political movements, environments, and transformations is evident. 


\section{Feminist Translation and Queer Translation}

Feminist translation first, and then queer translation, have provided an important space of discussion and practice centered on the need and desire to disrupt and transform patriarchal, heteronormative, and gender narratives mainly presented in written form, particularly in literary, philosophical, sociological, and medical texts (see Simon, 1996; Flotow, 1997). In the case of feminist translation, it has produced translations and translation processes and strategies that put normative expectations of translation, homogeneity, and rules aside. It has also made sexist practices evident and has led to the recovery and construction of women-oriented textualities and meanings. As Luise von Flotow points out,

Feminist work wants to disrupt acceptable, mainstream reading and writing and understanding; it wants difference. Further, it wants to draw attention to women translators' work -to the translator effect. It is logical then for feminist translation to stress difference, deterritorialization (the fact that the text has been taken out of its territory), displacement (the exile of the text into another culture) and contamination (the confluence of source and translating languages), rather than fidelity or equivalence. (1997, p. 44)

Translation processes in this context have deployed both new and old strategies and devices that acquired and produced unexpected and unconventional meanings through their re-ideologization and new focus in order to serve overt feminist purposes. Among possible devices and strategies, are supplementing, prefacing and footnoting, and hijacking as presented by von Flotow (1991, pp. 74-80). Also included are the re-ideologization of traditional ones very much in the line of Antoine Berman's endowing devices with considerations of their textual and discursive implications (2000). What could have otherwise been apparently neutral tools for translation, when handled with explicit feminist perspectives can both convey and profit from the workings of difference, deterritorialization, displacement, and contamination, as assets and not faults or even failures. Besides, the translator effect and translator function-the latter seen as a possible hybrid of what Myriam Díaz-Diocaretz (1985) and Douglas Robinson (1996) propose-are equally relevant, since they point at the textual practices and outcomes produced by the translator as a textual figure herself and as an entity that takes part in discursive mechanisms 
and narrative lines that create meaning. ${ }^{3}$ Although the foucauldian overtones lead to taking both concepts as audience effects produced by an array of textual, social, and cultural expectations and practices, at the same time they also hint at the historical and empirical agent responsible for the process of translating, who (consciously) leaves her textual mark in the translated text for the audience to receive and create meaning out of.

As part of the project of making academic inquiries locally relevant, it is important to say beforehand that there is the danger of a possible depolitization of "queer" - and therefore queer translationthrough its wide acritical popularization and probable systemic cooptation. It may become an umbrella synonym of anything that can seem to be non-conforming in terms of gender, sex, sexual orientation, and physical appearance, without necessarily having an explicit social, political, and cultural purpose. This can be seen, for example, in some queer entertainment venues, and in academic spaces where "queer theory" is one approach in a course syllabus, put in the same basket with other possible theorizations and methodologies, without pointing at

3. A possible issue with Díaz-Diocaretz's proposal is its ambiguity. It suggests either an ideal (yet sometimes) empirical translator, the work or the workings of a translator, the role of the translator, "translator" as a sort of methodological tool, and the function of the translator. Yet, in her concluding remarks she states, somewhat paradoxically: "Much more important than the consideration of the translator as an individual, whether male or female, is an understanding of a meaning-generating network called translator-function defined as including: (1) the individual and the corresponding concrete circumstances (2) a given socio-cultural context (3) a particular interpretative operation (4) a specific reading role (5) the translator's relation to source and receptortext (6) a specific writing role (7) the textual features through which the activities as omniscient reader and acting writer become evident or traceable and by means of which the receptive disposition of the readers of the translation is designed. The modes of integration of all these properties is what constitutes the translator-function" (1985, p. 151). When speaking of Díaz-Diocaretz's translator-function, Robinson seems more inclined to a foucauldian version based on the author-function, and says that "it would suggest that the idealized roles that society assigns actual translators, the way societal Others 'speak' us as translators, guide our transfers from source to target cultures in socially acceptable ways" (1996, p. 30). However, if for him "[t]he translator-function in Díaz-Diocaretz's sense is the translator's public mask, designed, constructed, and maintained in order to control readers' approach to the target text" (ibid.), it is worth remembering that for Díaz-Diocaretz the translation-function seems to be much more empirically close to her own self-idealization and realization as an active subject that controls the translation process. For the time being, a combination of the two possibilities suits my purposes here. There is a translator-function that depends and is built on social and political expectations that the translator-function fulfills in the doings of the publicly masked empirical subject in charge of the translation. 
social and political specificities and implications for the everyday life of real communities. In the same way as it is known to have happened with the term "gender," "queer" implies a crucial problem of cultural translation and runs the risk of acritical globalization regardless of local social, political, and cultural circumstances (see Platero et al., 2017, pp.9-18). Although embraced in some Hispanophone academic circles, "queer" is hardly a universal term and it has yet to be rewritten as a discourse in order to address local troubles and gain political relevance (see Domínguez Ruvalcaba, 2016, pp. 1-18). Just as "gay" has a different scope in English and in Spanish, "queer" in Mexico doesn't imply the political resignification of a derogatory term, and it doesn't necessarily imply a politically conscious questioning of gender-sex binary alignments. Far from that, "queer" is an anglicism associated with a middle and upper middle-class social status that may be recognized and used mainly by those endowed with power, mobility, cultural capital, and academic knowledge (Vargas, 2014, p. 165). It alludes not only to possible matters of sex and gender, but also takes for granted privileges of class and pigmentocracy, so it may be a socially restricted and exclusive, elitist and less politicized term. Therefore, in a social environment where "queer"-when it is usedimplies class and ethnic status, and in an academic environment where "queer" is just beginning to be present as a feasible theoretical stance because of its promise of political mobilization notwithstanding its possible cultural and intellectual elitism and colonization (see Parrini and Brito, 2014, pp. 8 et seq.), I want to make clear that, somehow paradoxically, I am using the term to refer to a theoretically supported way of thinking and acting that can comment on, criticize, dissect, and disrupt binaries, as well as narratives, paradigms, and expectations based on binaries. It is also a way of questioning traditional referent/ meaning and gender/sex/sexual orientation/gender expression associations, of exploring the social, cultural, and political dynamics that have historically supported those binaries. It is a means of coping with and even inhabiting ambiguity, that can offer methodological and theoretical views to fields such as Translation Studies, which is akin to the queer problematization of issues such as representation, otherness, authorship, and subjectivities (see Baer and Kaind1, 2018, pp. 1-3).

What has been referred to as "queer translation" in the Global North is an approach that, in a first stage, simultaneously runs parallel to and continues the feminist explorations of the textual reproduction and representation of sex/gender non-conforming experiences in 
concrete cases that address the recognition of the arbitrariness of meaning-producing practices that adhere to binary notions of sex and gender. With the development of queer theory-particularly the explorations of performativity - it is not only the arbitrariness of practices that is denounced and explored, but the very bases that produce, support, and naturalize that arbitrariness. Indeed, those that correspond to the mechanisms of the construction of gender as a norm that triggers further norms, regulations, and constructions (Butler, 2004, p. 41). As Butler develops throughout Undoing Gender,

Gender is the apparatus by which the production and normalization of masculine and feminine take place along with the interstitial forms of hormonal, chromosomal, psychic, and performative that gender assumes. [...] Gender is the mechanism by which notions of masculine and feminine are produced and naturalized, but gender might very well be the apparatus by which such terms are deconstructed and denaturalized. [...] To keep the term "gender" apart from both masculinity and femininity is to safeguard a theoretical perspective by which one might offer an account of how the binary of masculine and feminine comes to exhaust the semantic field of gender. Whether one refers to "gender trouble" or "gender blending," "transgender" or "cross-gender," one is already suggesting that gender has a way of moving beyond that naturalized binary. (ibid., pp. 42-43)

Gender is thus seen as a constructing and structuring element, not only a result but a social mechanism that produces notions. It is seen as a naturalizing process which is one of the reasons why gender performativity may be seen as an allegory of reality construction and reproduction (ibid., p. 30). Similarly, and due to the analogical/allegorical possibilities of gender as a reality construction and structuring mechanism, and translation as a structuring concept (see Harvey, 2014, p. 6), sexuality and translation can be put together because of the way both tend to be taken for granted. At the same time, they are both political acts and sites of personal and ideological struggle since they work with the textualization of identities and desires that condition the ways people relate to and construct their world.

Just as feminist translation has done, queer translation has been attempting to find unconventional, different ways to name and represent in and through translation, profiting from poststructuralist stances on meaning, textualities, and subjectivities, that are useful to problematize the relation between source and target texts. Questioning the hierarchies of that relation is not exclusive of feminist translation 
and queer translation. André Lefevere has also pointed out that it is the translation that produces the original $(1995$, p. 9). This is a view that affects epistemologically the terms of translating and translation expectations, and that initiates a re-thinking and transformation of binary paradigms in the disciplinary field. Lefevere's exploration does not work with the crossings of gender and translation but signals the overall binary thinking that has prevailed in the field of translation at least in the so-called "Western World," and that relates to notions of textuality and authorship. However, it can be re-read from a queer theory approach and used to help strengthen the theoretical association between translation and gender, mostly through the gender and queer revision of performativity:

[...] the widely cited point that Gender Trouble made was the following; that categories like butch and femme were not copies of a more originary heterosexuality, but they showed how the so-called originals, men and women within the heterosexual frame, are similarly constructed, performatively established. So the ostensible copy is not explained through reference to an origin, but the origin is understood to be as performative as the copy. Through performativity, dominant and nondominant gender norms are equalized. But some of those performative accomplishments claim the place of nature or claim the place of symbolic necessity, and they do this only by occluding the ways in which they are performatively established. (Butler, 2004, p. 208)

In a similar way, the relation between "original" and "translation" is affected by the realization of how performativity intervenes in their creation, thus showing the artificiality of the positionings that those roles and identities imply, something that can transform concepts, their relationality, and the processes they are involved in.

Taking into account the feminist roots of queer translationwhich can be traced back to feminism and gender/sexual/desire non-conformism as core issues for the founders of the Canadian journal Tessera in the 1980s-, feminism can be seen to provide queer approaches with a political grounding that may enrich the thinking and practicing of translation. Deborah Giustini puts it clearly when she says,

The contexts and forms of oppression are obviously different, and so of necessity queer translation in practice will take a different shape, but feminist subversion gives us a good starting point for inverting the hidden power relations of heterosexism by revealing and underscoring it through techniques borrowed from feminists. $(2015$, p. 7$)$ 
Despite the complex relations within a set of different forms of feminism because of their take on trans issues, perhaps it can be said, not unproblematically, that feminism's focus on violence against women and based on bodies allows for the association between queer and feminism. As Domínguez Ruvalcaba mentions, both "queer" and feminism focus on the body as a public concern whereupon politics can be based, just as it can trigger further discussions (2016, p. 13), some of them based on the need to counteract systemic and phobic violence against bodies (see Butler, 2004, pp. 8 et seq.). Moreover, if the instability of the sign "woman" is incorporated-something which can be objected to-, as part of the undoing of dichotomies by performativity, and "woman" itself is seen as the core of some transfer, as Godayol suggests, polarization and antagonism can be avoided (2005, p. 12). ${ }^{4}$

Queer notions in translation can help it transform its textual work with and within binary paradigms, and they can contribute to dismantling expectations and assumptions based on binaries, and thus even transform what is meant by "translation" itself. At the same time, a feminist focus can provide it with a clear political stance and anchor which can widely, albeit problematically, encompass sex/ gender non-conforming individuals' and women's texts, experiences, and views, in social and cultural contexts where "woman" still implies disadvantageous and even dangerous systemic positionings. The vulnerability that is apparent in and around bodies conceived of as "others," and the need to transform the narratives that are at the root of, and a product of, that vulnerability, may be shared points for feminist translation and queer translation. Given their possible disruption and transgression not only of established images and narratives but also of linguistic and literary norms, both feminist and queer translation tend to upset normative interests and translation practices that are rigidly based on binaries and discourses of authority.

4. Godayol proposes that "[o]nly by accepting that the category 'women' represents the fluid base of its practices can translation as/like a woman free the concept from the binary notions which currently frame all discussion. In this way, the category 'women' may be used in future discourses, including those of translators, as one which is open to revision and (re)signification. Only if, in contrast to the static meanings of hegemonic discourses, the idea frees itself from formulation in terms of dichotomies where, mistakenly, binary oppositions are simply mutually exclusive and never mutually communicative, will we be able to speak and reflect about the (im)possibilities of identifying the feminine subject in translation" (2005, pp. 12 et seq.). 


\section{Action and the Performative}

Translation is an action and a performative event. A political dimension can be added to the apparently simple functionalist sense of action as something associated with intentionality and change (Reiss, 2000 , p. 161; Nord, 2012, p. 16), which already make of translation a culturally active process.

[...] a translation is not simply a text but an act, and the function of the translation is as important as the content, the context as important as the text. The text itself becomes a performance. In a charged multilingual political context, translation is in fact a public action. (Tymoczko, 1999, p. 296)

Translation is then an explainable, intentional doing that attempts to produce a change, and that, in political contexts - as all contexts actually are-has public implications.

In J. L. Austin's proposal of speech acts, and specifically of performative utterances, stating can be the performing of an act. Speaking is a kind of action when marked by the use of a specific formula"verbs in the first person singular present indicative active" (1962, p. 5) such as "I promise," "I name," "I bet"-in specific appropriate circumstances by specific appropriate people in a ritualized way (ibid., p. 26). Initially, "(1) the performative should be doing something as opposed to just saying something and (2) the performative is happy or unhappy as opposed to true or false" (ibid., p. 132). However, these criteria are questioned when Austin has to explore the very foundations of his proposal and ponder what "doing" may mean, and finds that the truth (or falsity) of a statement goes beyond the meaning of words and has much more to do with "what act you were performing in what circumstances" (ibid., p. 144). So, much to some of his critics' and followers' chagrin, later in those lectures-and to some extent based on the problems found in "parasitic uses" of performatives, the little distinction between statements and performative utterances, exceptions to the formula such as the possible use of other persons, voices, and moods, and the vagueness of the very notion of "doing something"- he offers the idea that any utterance can in some way be both constative and performative-describing and doing-at the same time. Similarly, locutionary and illocutionary may be part of the same "genuine" speech act (ibid., p. 146), and he finds the list of solely performative verbs difficult, if not impossible, to strictly define and offer and he goes instead to speak of the illocutionary force of utterances and illocutionary acts carried out in those utterances (ibid., 
p. 149). A key element in the transformation of Austin's approach is found in his realizing that there are no pure performatives, that that false idea is based on a dichotomy of constatives and performatives (ibid., p. 149) and that "what we have to study is not the sentence, but the issuing of an utterance in a speech situation, [so] there can hardly be any longer a possibility of not seeing that stating is performing an act" (ibid., p. 138), which makes the distinction between constative and performative fade away more clearly.

Following Austin's wider proposal of performative utterances and illocutionary acts, translation can be regarded as a speech act produced at a concrete point in space and time, that can take an active part in social and political movements. To this it could be added that performative utterances, in their enunciation, are actions that generate effects and activate an iterative construction through citational processes (see Parker and Sedgwick, 1995, pp.1-18). Moreover, since performativity is not just circumscribed to utterances but is a general property of language (Sedgwick, 2003, p. 5)—which itself produces reality-, then translation, as an action, a process, and a product that is bound to language, is by definition marked by performativity. Besides, and given the impasse rendered by Austin's controversial twist when he comes to see constatives and performatives as not clearly set apart, and fails to produce that list of verbs, Sedgwick's periperformative is most useful: "though not themselves performatives, they are about performatives and, more properly, [...] they cluster around performatives" (ibid., p. 68). The mobile and not strictly hierarchical spatiality of such utterances endows them with a flexibility that goes beyond the already blurred Austinian performatives. There's therefore hardly any use in the search for a strict answer to the question of whether translation is a performative. I, however, insist that it is, and more evidently in Austin's finding utterances that can seem to be constatives but imply performatives and vice versa. In this new alternative configuration, the relation between "original" and "translation" is deprived of its hierarchical foundations, and translation reflection and criticism can be seen as related to performativity as well when they can be read as periperformatives.

Yet translation can be seen as performative in the sense presented by Butler when she speaks of gender construction ("gender is an identity tenuously constituted in time, instituted in an exterior space through a stylized repetition of acts" (1990, p. 140)) and later on as an allegory of how "reality is both reproduced and contested" (2004, 
p. 218), which allows for its use as a way of understanding a full range of meaning creation processes. For her, in the performative, repetition (citation and iterativity) and provisionality produce temporary gender meanings and signs based on norms, and it must be emphasized that

If a performative provisionally succeeds (and I will suggest that "success" is always and only provisional), then it is not because an intention successfully governs the action of speech, but only because that action echoes prior actions, and accumulates the force of authority through the repetition or citation of a prior and authoritative set of practices. It is not simply that the speech act takes place within a practice, but that the act is itself a ritualized practice. What this means, then, is that a performative "works" to the extent that it draws on and covers over the constitutive conventions by which it is mobilized. In this sense, no term or statement can function performatively without the accumulating and dissimulating historicity of force. (Butler, 1997, p. 51)

Performative acts are then not actually related to intentions but to repetition within a frame of historicity. Particularly in their actions of citation and repetition, they refer to previous norms and narratives that are relevant because they invoke authority and have themselves developed into authority. However, despite their authority, norms are not completely static as proved by trans bodies that exceed and transform them (see Butler, 2004, pp. 27-29). Furthermore, following polysystemic mechanisms, they cannot be completely static if they are to survive and last.

\section{Authority, Binaries, and Translation}

Authority - a point at the root of performativity and narrativitycontinues to be a central issue in translation in Mexico and Latin America (see Willson, 2004; Pagni, Payás, and Willson, 2011). This can be seen in publishing guidelines which may be either openly stated or taken for granted, the scarce book reviews that include a few remarks about translation, panel participation at conferences, and, last but not least, linguistic discussions about "deviances," which point at an overall conservative, even punitive, attitude towards translation (see Santoveña et al., 2010). The mere fact that including translators' names in the reference section of texts is not very popular even in academic circles is proof of that since it shows that the way translation is regarded still depends on norms based on linguistic and authorial presence and authority that obliterate the identity of a translated text as a translation. 
Some areas of literary studies in Mexico seem to be a long way beyond traditional binaries in that they question monolithic textualities in the acts of reading, theorizing and criticizing. However, paradoxically, translation seen from a literary studies perspective and when carried out by someone who is not an "author" still quite often faces the workings of authority and its power through the imposition of, and yearning for, a monolithically coherent and homogeneous kind of textuality that can be grasped through processes based on norms and binaries - and the corresponding expectations - that are then reproduced and reinforced, but that can also be transformed. Maria Tymoczko (2007, pp. 15-24) and Lawrence Venuti (1997) underscore the importance of positivism and of a Second World War and post Second World War instrumental communicative vision of translation as reasons for that kind of approach in the United States and the Anglophone world. That also applies to Hispanophone contexts, to which the Inquisition $\left(15^{\text {th }}-19^{\text {th }}\right.$ centuries), the Real Academia Española (the Royal Spanish Academy founded in the $18^{\text {th }}$ century), and several dictatorships in the $20^{\text {th }}$ century and their corresponding cultural policies should be added (see Godayol, 2017; Falcón, 2018).

The figure of the author keeps on being an additional element that supports normative views on translation. It has been theoretically and critically undermined, revised, and explored in elaborate ways that show it to be a complex compound of textual and social practices and phenomena (see Zapata, 2014). However, it seems that in the case of translation - a textual and social practice itself - the author still retains much of their role and aura as an individual auctoritas, as is evident in the Hispanophone publishing and academic world, and as can be seen-sometimes between the lines-in many of the interviews with literary translators in De oficio, traductor. Panorama de la traducción literaria en México (Santoveña, 2010), for example. The author figure is to some extent still regarded as the creator in a Romantic and Biblical sense, and as the owner of words and ideas which are in turn endowed with the power and authority of Logos in a process that allows the author to be the entity that originates, rules, and fixes the text. These images of author and text are reinforced by other discourses that have been strongly criticized by Tymoczko $(1999,2007)$ and Robinson (1991), among others, such as the long-standing relevance of sacred texts and the consequent status of the written word, as well as ethnocentrism, imperialism, sexism, classism, heteronormativity, and the deeply ingrained binary system that supports them all. 
The interactions of power, authority, and binaries have led to now naturalized prescriptive views of language and translation in ways similar to those that construct gender. They have affected the way we translate and reflect on translation to the extent that we tend to bring back discussions about the validity and status of "versions" and "adaptations" as modes of translation that depart from norms that seek to guard linguistic and textual integrity, coherence, and cohesion. They also motivate part of the translation jargon as when to the general opposition of binaries, translation binaries are added: original/ translation, source/target, author/translator, dynamic translation/ semantic translation, formal equivalence/dynamic equivalence, adequate/acceptable, literal translation/free translation, fluent/resistant, domesticating/foreignizing and so on. The norms that spring from these binaries and discourses have produced a kind of translation panopticon, and have as well reinforced the workings of linguistic, cultural, and national hegemonies. As a result of this, however conscious we are of what post positivism and poststructuralism have given to literary studies and even to translation studies, in the actual practice of translation in Mexico, there's a dutiful adherence to rules and guidelines aimed at the preservation of normative text and author images, that also depend on the authority of prescriptive linguistic institutions.

In Spanish, one example par excellence of the force and power of authority, and the search for the hegemonic and homogeneous, can be seen in the Real Academia Española (RAE). Founded in 1713, it is the official institution that oversees the Spanish language through its prescriptive dictionaries and grammars. In its beginning, its aim was "to fix the voices and words of the Castilian language with utmost propriety, elegance, and purity," expressed by its emblem-a crucible-, and its jingle-like motto "It cleans, it fixes, and it casts splendor" (Real Academia Española, 2016a, p. 6; my trans.). In 1993, the newly approved goals of the RAE became

to make sure that the changes the Spanish language goes through in its constant adaptation to its speakers' needs, do not fracture its essential unity in the whole Spanish-speaking world. Likewise, it must watch that this evolution preserves the proper genius of the language, just as it has been consolidated throughout centuries, and establish and spread the criteria of propriety and correction, and contribute to its splendor. (Real Academia Española, 2016b, p. 5; my trans.) 
The RAE goals are clear in terms of an institutional authority that guards the "homogeneous," "unified," and "correct" use of language, in what amounts to a colonial patriotism frequently verging on unintended humor, as R. Lucas Platero, María Rosón, and Esther Ortega call it when mentioning the RAE's indictment of anglicisms (2017, p. 10). Many a Hispanophone translator goes back to its texts for support when making decisions, and voluntarily accepts being constrained by its rules. So, translators and translations quite often preserve and reproduce uses of language that hardly correspond to the heterogeneous and quite fragmented and diverse realities of today. Interestingly, this mismatch happens particularly in political and social linguistic gestures that imply the questioning of basic concepts such as equivalence, fidelity, and accuracy seen as part of unified and homogeneous proposals of hegemonic world visions. This is the case of discussions about the use of inclusive and nondiscriminatory language, and the depiction of contemporary social and cultural situations and processes that have to do with sex-gender dissident non-hegemonic groups (see Díaz, 2019). Therefore, the notions of authority, prescription, authorship, sacredness, and binaries still make of translation in several parts of the Hispanophone world something that is rigidly regarded and based on instrumental communicative and positivist notions. These insist on the existence of a core of meaning that must be preserved and communicated in order to produce accurate and faithful renderings of the original. A direct consequence of this is the refusal-in target languages and texts, and in translating dynamics - to engage in social, political, and cultural lines of discursive transformation relevant for more heterogeneous and sex-gender non-conforming social spheres.

\section{Repetition and Difference as Elements for a Reader- and Translator-Oriented Approach}

A reader- and translator-oriented approach to translation-based on feminism, queer theory, and performativity-that attempts to critically work with and affect binaries and their unequal relations, may help to transform former views of translation still based on pre-1980s conventional notions of fidelity, equivalence, and concern for linguistic norms and structures, as they are currently held in some Hispanophone academic and publishing contexts where translations are assessed based on linguistic correctness-and where the limits seem to be set by grammatical and syntactical rules, and by morphology. Although Hispanophone academia, mainly in the 
humanities and social sciences, is already including perspectives from feminist, gender, and queer theory and studies-imported mainly from the Anglophone and Francophone academia, and also locally under construction-, those perspectives are not much resorted to in translation departments, reflection, and research. Similarly, the feeble link between academic translation sites and non-academic contexts -such as publishing houses and journalistic spaces-limits the social scope of academic observations. However, I consider that the incorporation of those perspectives into the basis of the way we think and practice translation in academic contexts may gradually permeate thought and practice of translation in a wider, non-academic field due to polysystemic dynamics and energies, and to an activist, or at least socially and politically concerned, take on translation. ${ }^{5}$

A reader- and translator-oriented approach that incorporates body, emotions, and the performative might, among other possibilities, posit the productive and beneficial codependence and coexistence of source and target texts that is already part of the periperformative and of gender construction, and thus disrupt traditional hierarchical orders, allow translator and reader to express their concerns and be active and empowered agents of the process of the creation of meaning. As a consequence it could contribute to a more general change in thought, conventions, and ways, as has been seen, from other different perspectives, in the case of some specific translations throughout history, as shown in Castro Ramírez when she explores the creation of a Mexican philosophical tradition through translation (2018), Godayol with her work on Francoism, censorship, and translation (2017), and Tymoczko's compilation showing different kinds of activism and social and political intervention through translation (2010).

Taking Austin's theoretical proposals into account, there is an initial way of presenting translation not only as something that performs in a wide sense of the word but also in the particular sense of a speech act. Translation is not only something one does but something that, through words, does in illocutionary and perlocutionary ways. For example, the transformation or reinforcement of a literary polysystem,

5. That may be the case of the translation of Gender Outlaws: The Next Generation into Spanish (Bornstein and Bear Bergman, 2010). Born in an academic context to foster trans visibility in Mexican society and contribute to the creation of writing models and antecedents in the target literary system that may help to support individual and community identity, it also focused on observing the decision-making behavior of the more than twenty translators that worked with a kaleidoscopic and heterogeneous range of texts. 
a rewriting or the creation of a metatext. It also does something specific through its transmutation into a metastatement, a critical commentary that necessarily speaks of the text while it makes the text and becomes the text. Besides, translation is performative in the sense of being a particular rendering in time and space of a text --taking us back to Austin's speech situations-- which implies interpretation as part of a reading practice and as part of an interpreting/performing exercise that will always be provisional and never final. In addition to that, as Katherine Davis suggests, decision-making also makes of translations performative events within the frame of a self-evident undecidability of meaning (2001, p. 51). Created anew at each utterance situation, meaning implies, then, the staging/performing of a set of specific actions that will be justified and determined by the historicity of the repertoire of choices. The series of decision-making moments render a chain of performative events where repetition and provisionality are key points. Furthermore, specific translations are parts of a sequence of moments that try to replicate the "original" in what amounts to the citation of previous norms and texts, which are also performative elements themselves. They can be related to Tymoczko's layers of metonymical translations, where, based on the idea that each telling is a re-telling, each different translation is seen to render a different view of the text that interacts with other views and translations, and it also depends on the recognition of previous meanings, forms, and rules (1999, pp. 41-61).

As it has been pointed out, performativity theoreticians recognize how the performative and performance depend on the existence of previous authoritative rules and their continuous repetition. That is to be linked to the fact that, as Robinson mentions when explaining metalocutionary implicatures, the use of words and expressions that are recognizably suitable for specific situations is the result of an unconsciously acknowledged history of their use that has been constructed by iterative processes-including processes of somatization-that produced the naturalization of the expression (2003, pp. 205-210).

Your own usages feel deeply motivated because you learned them slowly, iteratively, through thousands upon thousands of repetitions, supported and complexly retonalized by many different members of your speech community; the alien usages feel unmotivated, therefore arbitrary, therefore bizarre, because you encounter them without the history. (ibid., p. 206) 
As for queer theory and feminism, they have worked for the exploration and destabilization of gender roles, heteronormativity, and akin structures-which imply a set of historically rooted and deeply ingrained norms - through both the theorization and empirical experience of collectivities that do not conform to normative alignments of sex/gender. Their explorations can reinforce the dismantling of the way we relate to authority as if it were natural and should be taken for granted. Also, in the mechanisms of performativity that they use and show as theoretical, critical, and operative toolsthe application to translation and texts of mechanisms and criteria similar to those of sex/gender difference and performativity-, they can also liberate translation from this naturalization of authority and translation procedures, currently based on fidelity, unity, sameness and likeness, and homogeneity.

This performative side of translation reinforces, just as gender does, that meanings and identities are not natural but social and historical, and that they depend on previously established rules and norms. They are constructed through specific acts of repetition that cite previous acts of repetition. This sequence of acts unveils how derivative the "original" is, and emphasizes the fact that a text is an endless incomplete work. Gender and translation are never finished objects but unfolding constructions-in-progress where change and difference play a major role. As Sara Ahmed states in The Cultural Politics of Emotion,

A performative utterance can only "succeed" if it repeats a coded or iterable utterance: it works precisely by citing norms and conventions that already exist $[\ldots]$. Importantly, the historicity of the performative and its role in the generation of effects cannot be separated. If the performative opens up the future, it does so precisely in the process of repeating past conventions, as to repeat something is always to open up the (structural) possibility that one will repeat something with a difference. (2004, p. 93; my italics)

Past conventions, rules, and discourses are a mandatory element in performative processes. They define, guide, give direction, and they also coax and exclude through the way they do that, in a paradoxical move that puts together conforming and resisting to norms (see Butler, 2004, pp. 204 and 217), something that is part of the dynamics of repetition. The target text will never be in a relation of literal sameness and complete likeness to the source text. This is the case whether this is the result of the common mechanisms of reading, 
textuality, and translation, or of projects with specific purposes that deliberately create distance between source and target texts. So, there is unlikeness in translation notwithstanding that repetition may attempt a likeness through different notions of equivalence just as there is mimicry in mechanisms of gender construction that attempt to reproduce a predetermined, artificially constructed model of gender expression, many times to no avail. Here, gender norms are reproduced and invoked by body practices that can also affect and change them (Butler, 2004, p. 52). Difference, then, cannot be avoided or prevented, it is an inherent part of repetition in gender, and in translation when the latter is acknowledged as a series of performative utterances-and as a whole illocutionary act in itself. Those utterances can take place at one translation occurrence precisely located in one time and one place, where difference is produced in the dialogue between source text and target text. Or, as in the case of retranslations, at different moments and in different situations, where difference emerges and is found in the polyphonic conversation between several interacting metonymic layers of translation. It is in that difference, in the productive impossibility — perhaps an infelicity, going back to Austin — for gender acts and translation acts to reach the ideal however much they try to imitate it, that fissures can appear in the norms and narratives, and in the ritualized act which is also a side of the performative.

Gender acts are citational, yet each time the act of citation tries to mimic and approach the ideal, contexts can change, and unforeseen meanings can emerge. Queer sexuality thus reveals the basic instability of gender which, as both an analogy and a core source of meaning, sense, and structure production underlies the way meaning is created through language, narrative, and translation in acts that are not fully determining and cannot fulfill ideals and expectations. Hence gender is revealed to be a foundational element that both creates and is created, that does and undoes itself. This is similar to the workings of narrative that, according to Baker, "both reproduces the existing power structures and provides a mean of contesting them" (2010, p. 30).

The result of a series of repetitions can be a distorted image of the ideal, something that, in translation, leads to the notions of refraction and the problems of equivalence, a concept marked by its ontological and epistemological impossibility, and that is at the center of some of the main problems of meaning, performativity, and translation. Repetition itself can thus fissure the authority it might be supposed to reclaim and reinforce. Ironically, it is at this apparent point of 
failure where performativity, gender, and translation can open up for unexpected dislocated meanings and possibilities in a movement that resembles the dynamism of polysystems which is mandatory for their survival. The performative failure that is part of the tensions implied in the workings of repetition and difference produces the kind of change that makes for the survival of texts, at the same time that it implies a critical relation with the norms that define intelligibility and center stage translation concepts such as equivalence. As Butler explains,

the speech act, as a rite of institution, is one whose contexts are never fully determined in advance, and [...] the possibility for the speech act to take on a non-ordinary meaning, to function in contexts where it has not belonged, is precisely the political promise of the performative, one that positions the performative at the center of a politics of hegemony, one that offers an unanticipated political future for deconstructive thinking. (1997, p. 161)

Thus, the dis-location of the speech act, which implies an unlikeness as regards previous similar speech acts, in the end opens the way for the disruption and transformation of norms, narratives, and authority through translation procedures. The incapacity to reach the ideal in the attempt to accomplish it is the capacity to disrupt it and to show that it also depends derivatively on the repetition of discourses, and therefore it has no inherent meaning and value.

\section{Body and Emotions as Elements for a Reader- and Translator- Oriented Approach}

Both gender and translation encompass not only textual and discursive practices but also bodily practices. While this may be self-evident when related to gender, in the case of translation it is necessary to state that speaking is a bodily act even in a very physical sense, and performativity is about speech and bodily acts (see Butler, 2004, p. 172 and p. 198). The body, as the site of citation and discourses, reminds us of the binary division of bodily sex, reveals binaries to be cultural and not natural categories, and is the place where the performance of a set of acts constructs identity and gender. The body becomes the locus where the non-alignment of sex/gender/sexual orientation/gender expression/desire is manifested, and where the lack of certainties and equivalences, and the production of ambiguities and incoherence can be seen. Analogously, difficulties and ambiguities are at the core of literary texts due to polyglossia, polysemy and "textual openness [which] results from the multiplicity of meanings generated by 
reader response" (Tymoczko, 1999, p. 156). The body has also been part of translation theory when we follow the links between speech and bodily acts, and then between the performative as a general trait of language, and translation as an act of language. Robinson has insisted on its role in binaries where it is the spirit's counterpart at disadvantage, just as form and content, emotions and reason, original and translation are in disparate, unequal relations (1991, pp.3-64). Even if we questioned its role in translation, it belongs to a system of thought that associates body and translation as belonging to the same side in a binary structure that debases the physical/material as secondary and derivative expressions of a higher spiritual entity equal to essence and originality - ironically, one of Austin's problems appears when he refers to "the outward and visible sign [...] of an inward and spiritual act" (ibid., p. 9). Seen structurally and systemically, body and translation share points in common, take part in similar social, political, cultural, and textual processes and phenomena, and play complementary parts in related mechanisms of meaning production.

In a more specific theoretically relevant way that may be methodologically useful, Robinson proposes that

meaning and its interpretation are motivated and guided by feeling, or, more broadly, by body or somatic response; but that guidance is both contextually and personally variable $[\ldots]$ and ideologically controlled. (ibid., p. 10)

He thus presents the notion of the somatics and somatic markers in translation as part of the process of decision-making. Robinson's idiosomatics and ideosomatics include body responses, and bodily related hints and attitudes that can be associated with emotions and mental processes. These, constrained by their prior ideologization, are involved in the process of translating, with ideosomatics corresponding to a social level and idiosomatics to a personal, individual one-yet it is made clear that idiosomatics is also the result of social and cultural procedures that shape the individual's actions and responses (ibid., pp. 15-38), and that, together, they construct the history of the expression, which will trigger and explain automatic responses.

Members of groups (families, genders, social classes, national cultures, etc.) respond in similar ways to similar situations because those groups tend to "train" the bodies of their members to mark stimuli in similar ways- the source of "ideosomatics" - but this training is never monolithic. Each individual belongs to many different groups, and the overlaps between them will be different for different individuals; and 
every individual has many social experiences that no one else has, indeed that may from a collective point of view be entirely "random," so that the somatic markers associated with those experiences will be strikingly different from those of any other members of the various groups to which a given individual belongs. This latter, again, would be what I called "idiosomatics." Every use of language is both collectively controlled, or ideosomatic, and thus a form of repetition, and individually divergent or creative, idiosomatic, and thus a vehicle of change: the somatics of language, then, as the embodied channel of iterability. (Robinson, 2003, pp. 76-77)

The individual's physical actions and responses when translating - and when evaluating one's translations as well-are also performatively produced by culture even at the idiosyncratic level. Moreover, the interplay of ideo and idiosomatics reflects the interaction pattern between repetition and change/difference that is at the core of performativity and gender construction.

Relating the relevance of the body in translation to queer bodies as sites that incarnate and show the complexities and artificialities of sex/gender construction, emphasizes the role of performativity, ambiguities and inconsistencies in the two fields. It also opens the way to incorporate emotions as a potentially central element in a readerand translator-oriented approach to translation. For this, I resort to Ahmed's exploration of emotions as performative cultural practices and not (only) psychological states, as something that questions dualisms and is impressed on bodies, and that has effects on different kinds of collectivities and spaces.

Ahmed states that "[e]motions shape the very surfaces of bodies, which take shape through the repetition of actions over time, as well as through orientations towards and away from others" (2004, p. 4). This puts her views on emotions within the frame of the performative and the body. Her explorations of love and hatred (we love likeness and hate unlikeness), and disgust, are relevant to the discussion of translation. Most observers - in the case of translation, readers and, frequently enough, translators as well-appreciate, if not love, ruleabiding translation acts and gender acts that resemble an "original," that fulfill and gratify our expectations of what a translation or a person should be and look like, and how they should perform, act, and circulate in any social and cultural environment. The moment when they depart from the expected, unlikeness is perceived and uneasiness and rejection, if not hatred, are produced, which can then lead to disgust at seeing something that "offends the eye" and elicits 
a negative-sometimes visceral-response. Those emotions may be identified as the result of reading what, according to local conventions, may be considered a "fluid," "good" translation, or one that "sounds awkward," "wrong," one that parts from the "original" and from the norms that are expected to be followed.

Perhaps one of the emotions that may more clearly relate to gender, queerness, and translation, is shame. As discussed by Ahmed, and, as in Sedgwick who takes it as the queer emotion by definition (2003, pp. 35-65 and pp. 93-121), having its conceptual roots in psychology, shame is produced when a self-image is not achieved or maintained, when the individual is found at fault. In other words, it is produced by the failure to live up to a social ideal (Ahmed, 2004, pp. 106 et seq.). In Ahmed's account, it is important that there is an other that witnesses the individual's impossibility to reach social, personal, and self ideals. Just as in the case of trans bodies the difficulty to embody the sex/ gender ideal may be a cause for shame or for being shamed (even for being murdered), translators are ashamed and shamed (sometimes to their lives' risk) when they do not fulfill ideals of certainty, faithfulness, accuracy, coherence, and adequate and acceptable communication that authoritative normative discourses impose. Going back to a translation already handed in and even published often enough implies a moment of shame when "mistakes" or "unjustified differences" are found, and the translator catches herself at fault or has to face accusations of being at fault.

If emotions are impressed on the body, just as bodies take the shape of norms that are repeated over time, and emotions are part of the body's physical codes and reactions (dropping one's head, standing straight, blushing, slouching), they certainly are part of Robinson's idio and ideosomatics, and of a translator's expected and codified actions and reactions as the subject that performs the speech act. Shame sticks to the body and creates first an individual impression on it - and then a collective impression-triggered by social models and expectations when translators are caught "at fault" as regards ideals of translation often centered around binary, ethnocentric, sexist, and heteronormative tenets that insist on unity, coherence, and homogeneity. Yet shame is also shared and lived in parallel with the reader when she, based on prescriptions and norms, shames the translator, but also when the reader is ashamed and shamed by those same prescriptions, narratives, and norms that rule and determine her reading, decoding, and evaluating processes. Moreover, if the reader 
considers herself part of the translator's community in the processes of creation of meaning implied by translation, she may also come to incorporate the translator's shame as her own, to have it stick to her body and impress it, when finding that she has also fallen into the same traps and risks -this as part of shame's double movement "toward painful individuation, toward uncontrollable relationality" (Sedgwick, 2003, p. 37) that may be of political conceptual import.

I propose that shame should not stop there. When shame leads to reading, translating, or textual discomfort it may allow for a strategic twist, an undoing of what's normally expected of it, and become a potentially important transgressive point which can be a rich moment in a reader- and translator-oriented approach to translation. This is similar to the generative discomfort discussed by Ahmed:

To feel uncomfortable is precisely to be affected by that which persists in the shaping of bodies and lives. Discomfort is hence not about assimilation or resistance, but about inbabiting norms differently. The inhabitance is generative or productive insofar as it does not end with the failure of norms to be secured, but with possibilities of living that do not 'follow' those norms through. [...] Queer feelings are 'affected' by the repetition of the scripts that they fail to reproduce, and this 'affect' is also a sign of what queer can do, of how it can work by working on the (hetero)normative. [...] Queer feelings may embrace a sense of discomfort, a lack of ease with the available scripts for living and loving, along with an excitement in the face of the uncertainty of where the discomfort may take us. (2004, p. 155)

Discomfort can become a long-lasting disturbing emotion that provides room for reflection and transformative action by all parties involved. It can be related to gender confusion as regards the identity of a person, for example. Or to the moments when a translated text makes us uncomfortable because it parts from linguistic and literary norms, and the translation is thus rendered "awkward," non-fluid, non-homogeneous, and, in the end, inappropriate and inadequate. For instance, when in an attempt to produce inclusiveness, translators choose not to get round grammatical gender marks through discreet gender-neutral expressions, but to use highly visible, concretely material, unsanctioned marks (x, @, stating "ellas y ellos," "ellxs" or "elles" in Spanish) that disrupt norms and threaten textual comfort and "normalcy." Another point of discomfort could be the blatant feminization and queering of terms that would otherwise reproduce the notion of the masculine universal. Or the production of (possibly 
"clumsy") repetitive structures that are absent from the source text but that may be useful in order to create effects that compensate for textual transformations due to gender (im)balances. These choices may produce discomfort in the translator who is aware of behaving in unexpected ways and therefore not fulfilling the normalized ideals. They may also produce an upsetting discomfort in the reader who grasps that the text does not even pretend to be satisfying current conventional expectations, therefore making her pay attention more carefully and critically to what is happening in terms of content and of the very workings of the mechanisms of meaning construction and representation. Discomfort may be a way to produce symptoms for the reader to dig into and to make them epistemologically useful. Furthermore, "clumsiness," "awkwardness," "discomfort," "inadequacy" can enter already existing conceptual-disciplinary narratives and dislocate them through apparent incoherence and lack of cohesion and become either neutral terms or even positive concepts and values.

Besides feeling shame when having to realize that the person or the text does not fulfill authorized mainstream expectations, discomfort can operate as a way to encourage and force us to confront the notion that something is amiss since the ideal is impossible to attain. This is basically because every repetition, every attempt to become the same with the ideal, is a priori marked by a series of systemic and textual inequalities and inadequacies, by a mixture of likeness and unlikeness, and by difference. A difference that may amount to the acceptance that equivalence is a deeply ingrained, culturally dependent construct that has also been enthroned by processes of iterativity. Also, a difference that may become unresolved fissures and voids where ambiguity can dwell and thus create other possibilities of representation and meaning production, as in sex-gender non-conforming bodies. Here, doing uncertainty, ambiguity, and incoherence in the interstices that disrupt an ideal-be it of gender or textual-while undoing equivalence as another ideal of gender and translation, can resemble the infelicities that mar a speech act, but which can be turned into points of rupture and devices that help undo binaries and certainties, and lead to generative and selective discomfort. This difference, which implies the impossibility of fulfilling gender, textual and translation ideals, can bring about productive shame and discomfort through translation devices and effects such as the ones mentioned in this text. Particularly, it can cause discomfort at finding equivalence expectations thwarted, and profound physical, emotional, and intellectual discomfort at 
having to cope with openness, incoherence, ambiguity, instability, and liminality. These aspects can become values and places of ethical and political resistance, as well as sites of meaning and knowledge.

Having transitioned with remaining impressions/imprints from the past, being in-between, "mimicking," transitioning without being allowed to "pass successfully," being illegible because body signs are mixed, confusing, and show fractures, and thus reveal how the models and ideals are empirically curtailed, may be, in some queer bodies, potential and unsettling moments of resistance and activism that question and undermine binaries. Translation's impossibility to be a replica of the "original" can be a space of resistance and activism as well if discomfort is maintained and rendered generative through triggering further "negative" emotions and responses in the reader. Translation can try to pass to no avail, just as it can deliberately show its politically motivated incapacity or unwillingness to pass. Translators, translation, translation processes, and readers, can move away from the binary in their expectations of translated texts and in their own translating and reading practices. This could bring about a point where translation would then also have the possibility of questioning thought and thinking practices.

\section{Conclusions}

This approach to translation requires one to reflect on the performative and emotional/affective use of translation devices, which can at some point lead to the use of the analytical vulnerability mentioned by Alba Pons Rabasa when she deals with the notion of an affective ethnography that recovers the epistemological status of emotions, and the possibility of producing knowledge out of the local and embodied (2018, pp. 14, 25, 49 and 50). It also implies the possibility of designing specific translation projects not only of feminist and queer texts, but also of other kinds of texts, where the iterativity, citationality, and provisionality of the performative can be at work with a clear focus on the interaction between reader and translator as active subjects aware of their own artificial self-construction through performativity. This may allow as well for the creation of feminist queer spaces of reflection and production for translations and readings that move away from and disturb and dislodge normative frames, narratives, and practices in translation.

Based on some of the moves made in queer theory, it can be seen that gender allows for the creation and discovery of a space 
that produces notions, vocabulary, dynamics that point at gender performativity and its components as an analogy and allegory of the construction and the questioning of reality and textuality. Together, queer theory and feminisms can provide theoretical, methodological, analytical and critical tools and stances in order to create flexible bases and models of knowledge, to redefine and reconceptualize the world, and to make sense out of some systems of world representation, thus turning into epistemological grounds for understandings of world constructions through representations and narrativity.

It is possible to theorize- - understood as a way not to say how to translate, but as a path to reflect on translation to try to understand its scope and its role in the creation of meanings, narratives, collectivities, and cultures-from these joint perspectives as a way to shed light on gender and its mechanisms as possible flexible paradigms. These, rooted in their epistemological function of knowledge construction and concept elaboration, can take part in social transformations when making identities visible, presenting experiences, and opening up options. This points to the mere possibility of fracturing the homogeneity and power that are taken for granted as the basis for a unified single narrative that excludes communities and individuals and puts them at risk.

\section{References}

Ahmed, Sara (2004). The Cultural Politics of Emotion. London and New York, Routledge.

Anon. (2019). "Feminicidios en México crecen 111\% en los últimos 4 años.” El Financiero, December 2. [https://elfinanciero.com.mx/nacional/111-masfeminicidios-en-mexico-en-los-ultimos-4-anos].

Austin, J. L. (1962). How to Do Things with Words. London, Oxford University Press.

Baer, Brian James and Klaus Kaindl (2018). "Introduction: Queer(ing) Translation.” In B. J. Baer and K. Kaindl, eds. Queering Translation, Translating the Queer. Theory, Practice, Activism. London and New York, Routledge.

Baker, Mona (2007). Translation and Conflict. A Narrative Account. London and New York, Routledge.

Baker, Mona (2010). "Translation and Activism: Emerging Patterns of Narrative Community." In M. Tymoczko, ed. Translation, Resistance, Activism. Amherst, University of Massachusetts Press.

Baldo, Michela (2018). "Queer Translation as Performative and Affective Undoing: Translating Butler's Undoing Gender into Italian.” In B. J. Baer and K. Kaindl, eds. Queering Translation, Translating the Queer. Theory, Practice, Activism. London and New York, Routledge. 
Berman, Antoine (2000). "Translation and the Trials of the Foreign." Trans. Lawrence Venuti. In L. Venuti, ed. The Translation Studies Reader. London and New York, Routledge.

Bornstein, Kate and S. Bear Bergman, eds. (2010). Gender Outlaws: The Next Generation. Berkeley, Seal Press.

Bornstein, Kate and S. Bear Bergman, eds. (2018). Disidentes de género: la nueva generación. Trans. Ariadna Molinari Tato et al. Madrid, Continta Me Tienes.

Bornstein, Kate and S. Bear Bergman, eds. (2019). Disidentes de género: la nueva generación. Trans. Ariadna Molinari Tato et al. Zacatecas, Texere.

Butler, Judith (1990). Gender Trouble. London and New York, Routledge.

Butler, Judith (1993). Bodies that Matter. On the Discursive Limits of "Sex." London and New York, Routledge.

Butler, Judith (1997). Excitable Speech. A Politics of the Performative. London and New York, Routledge.

Butler, Judith (2004). Undoing Gender. London and New York, Routledge.

Castro Ramírez, Nayelli, ed. (2013). Traducción, identidad y nacionalismo en Latinoamérica. Mexico City, Bonilla Artigas Editores/CONACULTA/ FONCA.

Castro Ramírez, Nayelli (2018). Hacerse de palabras. Traducción y filosofía en México (1940-1970). Mexico City, Bonilla Artigas Editores.

Davis, Kathleen (2001). Deconstruction and Translation. Manchester, St. Jerome. Díaz, Mario (2019). “Se acabó la discusión por el 'todes'No se acepta en la Real Academia Española." LV15, September 30. [https://lv15.com.ar/se-acabola-discusion-por-el-todesno-se-acepta-en-la-real-academia-espanola/?fbc lid=IwAR2xsaEgxxqV0zktAPiYQdgqo0X5RSQC1EnCDR_4FevxRB6o fwekepy7dBA].

Díaz-Diocaretz, Myriam (1985). Translating Poetic Discourse: Questions on Feminist Strategies in Adrienne Rich. Amsterdam, John Benjamins.

Domínguez Ruvalcaba, Héctor (2016). Translating the Queer: Body Politics and Transnational Conversation. London, Zed Books.

Falcón, Alejandrina (2018). "Cuatro grandes colecciones unidas para formar una gran biblioteca': la Biblioteca Total del Centro Editor de America Latina. Un estudio sobre la importación de literatura y ciencias sociales durante la última dictadura argentina." In N. Castro, A. M. D'Amore and P. A. Montoya, eds. Los estudios de traducción en América Latina. Una mirada a la región. Mexico City, Bonilla Artigas Editores.

Flotow, Luise von (1991). "Feminist Translation: Contexts, Practices and Theories." TTR, 4, 2, pp. 69-84.

Flotow, Luise von (1997). Translation and Gender: Translating in the "Era of Feminism." Manchester, St. Jerome; Ottawa, University of Ottawa Press.

Galván, Melissa (2019). "14 datos de la violencia de género que explican el enojo de las mujeres." Expansión Política, November 25. [https://politica. expansion.mx/mexico/2019/11/25/datos-sobre-violencia-contra-mujeresmexico. 
Giustini, Deborah (2015). "Gender and Queer Identities in Translation: From Sappho to Present Feminist and Lesbian Writers: Translating the Past and Retranslating the Future." Norwich Papers, 23. [https://www.academia. edu/14509189/Gender_and_Queer_Identities_in_Translation._From_ Sappho_to_present_feminist_and_lesbian_writers_translating_the_past_ and_retranslating_the_future].

Godayol, Pilar (2005). "Frontera Spaces: Translating as/like a Woman." In J. Santaemilia, ed. Gender, Sex and Translation. The Manipulation of Identities. London and New York, Routledge.

Godayol, Pilar (2017). Tres escritoras censuradas: Simone de Beauvoir, Betty Friedan y Mary McCarthy. Trans. Pilar Godayol, Granada, Editorial Comares. (Interlingua 164)

Guerrero McManus, Siobhan F. and Leah Muñoz Contreras (2016). "Transfeminicidios: una violencia estructural." Horizontal, October 21. [http://horizontal.mx/transfeminicidios-una-violencia-estructural/].

Harvey, Keith (2014). Intercultural Movements. American Gay in French Translation. London and New York, Routledge.

Lefevere, André (1995). "Introduction: Comparative Literature and Translation." Comparative Literature, 47, 1. [www.jstor.org/stable/1771359]. Nord, Christiane (2012). Translation as a Purposeful Activity. Manchester, St. Jerome.

Pagni, Andrea, Gertrudis Payás and Patricia Willson, eds. (2011). Traductores y traducciones en la historia cultural de América Latina. Mexico City, Universidad Nacional Autónoma de México.

Parker, Andrew and Eve Kosofsky Sedgwick, eds. (1995). Performativity and Performance. London and New York, Routledge.

Parrini, Rodrigo and Alejandro Brito (2014). "Introducción. La memoria y el deseo." In R. Parrini and A. Brito, eds. La memoria y el deseo. Estudios gay y queer en México. Ciudad de México, Universidad Nacional Autónoma de México/Programa Universitario de Estudios de Género.

Platero, R. Lucas, María Rosón, and Esther Ortega (2017). "Introducción." In R. L. Platero, M. Rosón and E. Ortega, eds. Barbarismos queer y otras esdrújulas. Barcelona, Ediciones Bellaterra.

Pons Rabasa, Alba (2018). "Vulnerabilidad analítica, interseccionalidad y ensamblajes: hacia una etnografía afectiva." In A. Pons Rabasa and S. Guerrero Mc Manus, eds. Afecto, cuerpo e identidad. Reflexiones encarnadas en la investigación feminista. Ciudad de México, Universidad Nacional Autónoma de México/Instituto de Investigaciones Jurídicas.

Real Academia Española. 2016a. "Estatutos." [http://www.rae.es/sites/default/ files/Estatutos_1715.pdf].

Real Academia Española. 2016b. "Estatutos y reglamento nuevo." [http://www. rae.es/sites/default/files/Estatutos_y_reglamento_nuevo.pdf].

Reiss, Katharina (2000). "Type, Kind and Individuality of Text: Decision Making in Translation." Trans. Susan Kitron. In L. Venuti, ed. The Translation Studies Reader. London and New York, Routledge. 
Robinson, Douglas (1991). The Translator's Turn. Baltimore, The Johns Hopkins University Press.

Robinson, Douglas (1996). Translation E Taboo. Illinois, Northern Illinois University Press.

Robinson, Douglas (2003). Performative Linguistics. Speaking and Translating as Doing Things with Words. London and New York, Routledge.

Santoveña, Marianela et al., eds. (2010). De oficio, traductor. Panorama de la traducción literaria en México. Mexico City, Bonilla Artigas Editores/ CONACULTA/FONCA.

Simon, Sherry (1996). Gender in Translation: Cultural Identity and the Politics of Transmission. London and New York, Routledge.

Sedgwick, Eve Kosofsky (2003). Touching Feeling. Affect, Pedagogy, Performativity. Durham and London, Duke University Press.

Tymoczko, Maria (1999). Translation in a Postcolonial Context. Manchester, St. Jerome.

Tymoczko, Maria (2007). Enlarging Translation, Empowering Translators. Manchester, St. Jerome.

Tymoczko, Maria, ed. (2010). Translation, Resistance, Activism. Amherst, University of Massachusetts Press.

Vargas, Susana (2014). "Saliendo del closet en México: ¿queer, gay o maricón?" In R. Parrini and A. Brito, eds. La memoria y el deseo. Estudios gay y queer en México. Ciudad de México, Universidad Nacional Autónoma de México/ Programa Universitario de Estudios de Género.

Venuti, Lawrence (1997). The Translator's Invisibility. A History of Translation. London and New York, Routledge.

Wilsson, Patricia (2004). La Constelación del Sur. Traductores y traducciones en la literatura argentina del siglo XX. Buenos Aires, Siglo veintiuno editores.

Zapata, Juan, ed. (2014). La invención del autor. Nuevas aproximaciones al estudio sociológico y discursivo de la figura autorial. Trans. Juan Zapata. Medellín, Universidad de Antioquia.

Julia Constantino Reyes

Department of Modern Languages and Literatures Universidad Nacional Autónoma de México Mexico City, Mexico juconstantinor@gmail.com 